\title{
UPAYA MITIGASI BENCANA GERAKAN TANAH DALAM PERSPEKTIF ISLAM (Studi Kasus Penambangan Pasir Ilegal Di Kecamatan Bangsal Kabupaten Mojokerto)
}

\author{
Sulfatul Fadlilah $^{1}$, Adi Susilo ${ }^{2}$ dan Bagyo Yanuwiadi ${ }^{3}$ \\ ${ }^{1}$ Program Pasca Sarjana Univesitas Brawijaya, \\ ${ }^{2}$ Jurusan Fisika, Fakultas Matematika dan Ilmu Pengetahuan Alam Universitas Brawijaya \\ ${ }^{3}$ Jurusan Biologi, Fakultas Matematika dan Ilmu Pengetahuan Alam Universitas Brawijaya
}

Email: sulfatul_82@yahoo.com

\begin{abstract}
Ilegal sand mining after days was not restrained, and it caused land movement in every dikes of Brantas river. In Alquran, (Ar Rum:30) said that the disaster is made by the human, they have to chance the bad behavior/habits if they wants the disaster will not happen. This research has puspose for knowing the subjects of ilegal sand mining and how far the impact of sand mining. The methode of the research is quantitative and for the collect data are introgation, observation, and documentation to get more information about ilegal sand mining. In UU No 23 Year 1997, that every body have to keep environment to ward off the disaster. The government has to take any strategic ways to move the ilegal sand mining practice.
\end{abstract}

Keywords: ilegal sand mining, Islam perspective, disaster mitigation

\section{Pendahuluan}

Sebuah keharusan bagi setiap daerah untuk berkembang diberbagai sektor. Tidak terkecuali dengan Mojokerto. Seiring kemajuan zaman, maka banyak konsekwensi yang harus dipenuhi. Diantaranya munculnya permasalahan ekonomi, sosial, budaya, juga isu sara yang akhir-akhir ini sering muncul. Permasalahan yang tidak kalah peliknya adalah penambangan pasir liar yang sampai saat ini masih menjadi fenomena tersendiri. Bagaimana tidak?, disatu sisi adanya aliran sungai Brantas Mojokerto membawa berkah bagi banyak sektor tetapi disisi lain juga membawa bencana bagi sektor yang lain.

Penambangan pasir liar yang terdapat disepanjang tanggul sungai Brantas Mojokerto yang membentang dari Kecamatan Gedeg sampai Kecamatan Mlirip juga disepanjang area bendungan Rolak Songo semakin lama semakin tidak terkendali. Dari sepanjang area tersebut terdapat 115 titik penambangan pasir liar.

Kondisi Sungai Brantas Mojokerto yang memprihatinkan ini sudah seharusnya menjadi perhatian masyarakat dari segala lapisan. Konservasi Sungai Brantas Mojokerto tidak hanya menjadi tanggung jawab pemerintah saja. Berbagai program konservasi yang telah dilaksanakan pemerintah belum memberi hasil memuaskan karena hanya berakhir pada konsep semata.

Jika ditinjau dari aspek kebijakan pun, Pemerintah Provinsi Jawa Timur telah lalai dari kewajibannya mengelola kualitas air dan mengendalikan pencemaran di Sungai Brantas Mojokerto, minimal dengan melihat data dan fakta tersebut. Pemerintah Provinsi Jawa Timur telah lalai dari kewajibannya untuk melindungi kawasan bantaran sebagai kawasan lindung, sehingga mengakibatkan berdirinya bangunanbangunan industri, gudang, dan permukiman yang meningkatkan beban pencemaran. Tidak adanya kebijakan yang tegas tentang bangunan di bantaran sungai mengakibatkan semakin menjamurnya permukiman warga di sepanjang bantaran.

Dengan semakin terbatasnya kemampuan pemerintah karena meningkatnya tuntutan sektor-sektor lain atas pembiayaan dari anggaran pembangunan, program-program konservasi DAS, tampaknya, semakin telantar. Karena itu, sudah saatnya dipikirkan upaya keterlibatan masyarakat dalam upaya-upaya pengendalian pencemaran, pengawasan, serta pengelolaan Sungai Brantas Mojokerto. Keterlibatan ini tidak memandang usia. Anakanak, orang dewasa, maupun orang tua memiliki andil dalam konservasi Sungai 
Brantas Mojokerto. Jika hal ini dibiarkan, maka Mojokerto menjadi daerah rawan bencana yang setiap saat mengancam warga. Banjir, penyakit, longsor dsb akan menjadi bom waktu yang setiap saat akan meledak.

Pelibatan masyarakat mungkin bisa dilakukan dengan pengembangan kampungkampung atau desa-desa ramah Sungai Brantas Mojokerto yang memiliki kepedulian untuk menjaga kualitas air Sungai Brantas Mojokerto. Komunitas dalam kampung atau desa ini harus berperan aktif mengurangi tingkat pencemaran domestik sekaligus mengontrol buangan limbah industri.

Pemuda, mahasiswa, dan pelajar adalah agen perubahan yang harus berperan aktif dalam upaya pemulihan ekosistem Sungai Brantas Mojokerto yang akan menjadi pionir dan agent of change di keluarga serta masyarakat sekolah dan kampusnya. Kegiatan yang mereka lakukan bisa berupa kampanye konservasi Sungai Brantas Mojokerto secara khusus dan lingkungan hidup secara umum. Baik dengan terjun langsung membersihkan sampah sungai, menanam pohon, memanajemen sampah, atau pendekatan persuasif kepada para penambang pasir ,temanteman di sekolah, kampus, keluarga, dan masyarakat. Jika konsep ini terlaksana dan didukung masyarakat, kita masih bisa menaruh harapan akan masa depan Sungai Brantas Mojokerto.

\section{Metode Penelitian}

Jenis penelitian yang dipergunakan dalam penelitian adalah penelitian deskriptif (descriptive research). Menurut Narbuko dan Achmadi (2007), penelitian deskriptif yaitu penelitian yang berusaha untuk menuturkan pemecahan masalah sekarang berdasarkan datadata, jadi ia juga menyajikan data, menganalisis dan menginterpretasikan data. Tujuan dari penelitian deskriptif adalah untuk memecahkan masalah secara sistematis dan faktual mengenai fakta-fakta dan sifat-sifat populasi. Sedangkan teknik pengumpulan data menggunakan metode observasi, dokumentasi dan wawancara dengan pelaku juga instansi terkait.

\section{Hasil dan Pembahasan}

Sungai Brantas Mojokerto adalah sebuah sungai di Jawa Timur yang merupakan sungai terpanjang kedua di Pulau Jawa setelah Bengawan Solo. Sungai Brantas Mojokerto bermata air di Desa Sumber Brantas (Kota
Batu) yang berasal dari simpanan air Gunung Arjuno, lalu mengalir ke Malang, Blitar, Tulungagung, Kediri, Jombang, Mojokerto. Di Kabupaten Mojokerto sungai ini bercabang dua menjadi Kali Mas (ke arah Surabaya) dan Kali Porong (ke arah Porong, Kabupaten Sidoarjo). Kali Brantas mempunyai DAS seluas 11.800 $\mathrm{km}^{2}$ atau $1 / 4$ dari luas Provinsi Jatim. Panjang sungai utama $320 \mathrm{~km}$ mengalir melingkari sebuah gunung berapi yang masih aktif yaitu Gunung Kelud. Curah hujan rata-rata mencapai $2.000 \mathrm{~mm}$ per-tahun dan dari jumlah tersebut sekitar $85 \%$ jatuh pada musim hujan. Potensi air permukaan pertahun rata-rata 12 miliar $\mathrm{m}^{3}$. Potensi yang termanfaatkan sebesar 2,6-3,0 miliar $\mathrm{m}^{3}$ per-tahun.

Secara geografis DAS Kali Brantas melintasi 15 kabupaten/kota dengan jumlah penduduk di wilayah sungai Kali Brantas mencapai 15.884.000 jiwa (2005) atau 43\% dari penduduk Jatim dan mempunyai kepadatan rata-rata 1,2 kali lebih tinggi dibandingkan ratarata Jatim. Adapun DAS Kali Brantas mempunyai peran yang cukup besar dalam menunjang Provinsi Jatim sebagai lumbung pangan nasional. Dalam tahun 1994-1997, Provinsi Jatim telah memberi kontribusi ratarata 470.000 ton beras/tahun atau sebesar $25 \%$ dari stok pangan nasional. DAS Kali Brantas termasuk dalam Wilayah Sungai Brantas Mojokerto yang pengelolaan berada pada Balai Besar Wilayah Sungai (BBWS) Brantas.

Hasil pengembangan menghasilkan sejumlah besar prasarana pengairan. Manfaat pembangunan antara lain: pengendalian banjir 50 tahunan di sungai utama yang mengurangi luas genangan sekuas 80.000 ha; irigasi untuk sawah seluas 345.000 ha dimana 83.000 ha berupa irigasi teknis langsung dari sungai induk (2,5 miliar $\mathrm{m}^{3}$ per-tahun), energi listrik 1.000 giga-W-jam per-tahun, suplai air baku untuk industri 130 juta $\mathrm{m}^{3}$ per-tahun dan domestik 240 juta $\mathrm{m}^{3}$ per-tahun.

Penduduk di wilayah sungai Kali Brantas mencapai 15,2 juta orang (1999) atau $43 \%$ dari penduduk Jatim dan mempunyai kepadatan rata-rata 1,2 kali lebih tinggi dibandingkan rata-rata Jatim.

\section{Kerusakan Lingkungan di Mojokerto}

Pembuangan sampah di sepanjang sempadan maupun langsung ke aliran Sungai Brantas Mojokerto bisa merugikan penduduk sekitar dan di kawasan yang lebih rendah. Sampah yang menumpuk menimbulkan bau 
busuk karena fermentasi, menjadi sarang serangga dan tikus, serta bisa menimbulkan kebakaran karena adanya gas metana di tumpukan sampah.

Air yang mengenai sampah akan mengandung besi, sulfat, dan bahan organik yang tinggi ditambah kondisi BOD (bio chemical oxygen demand) dan COD (chemical oxygen demand) yang melebihi standar air permukaan.

Hasil pengukuran turbiditas air Sungai Brantas Mojokerto di Kota Malang, daerah yang masih tergolong sebagai hulu, menghasilkan kisaran angka 14 hingga 18 mg/l. Kisaran itu telah melebihi kekeruhan maksimum $(5 \mathrm{mg} / \mathrm{l})$ yang dianjurkan dari Baku Mutu Air pada Sumber Air Golongan A (Kep 02/MENKLH/I/1988).

Ditinjau dari rasa, air Sungai Brantas Mojokerto juga tidak sesuai baku mutu (Sunarhadi dkk 2001). Faktanya, terdapat sekitar 330 ton per hari limbah cair dihasilkan dari aktivitas manusia di sepanjang DAS Brantas. Sekitar 483 industri mempunyai pengaruh secara langsung terhadap Sungai Brantas Mojokerto dengan kontribusi pencemaran hingga 125 ton per hari (Antara News, 2006).

Kondisi makin memprihatinkan karena bantaran DAS Brantas di Jawa Timur mengalami perubahan fungsi. Meski kawasan bantaran sungai telah ditetapkan sebagai kawasan hijau, sebagian besar bataran sungai beralih fungsi, tidak sesuai peruntukannya.

\section{Penambangan Pasir Ilegal di Mojokerto Pertambangan adalah rangkaian} kegiatan dalam rangka upaya pencarian, penambangan (penggalian), pengolahan, pemanfaatan dan penjualan bahan galian (mineral, batubara, panas bumi, migas).

Ilmu Pertambangan: ialah ilmu yang mempelajari secara teori dan praktik hal-hal yang berkaitan dengan industri pertambangan berdasarkan prinsip praktik pertambangan yang baik dan benar (good mining practice)

Menurut UU No.11 Tahun 1967, bahan tambang tergolong menjadi 3 jenis, yakni Golongan A (yang disebut sebagai bahan strategis), Golongan B (bahan vital), dan Golongan $\mathrm{C}$ (bahan tidak strategis dan tidak vital). ${ }^{[1]}$ Bahan Golongan A merupakan barang yang penting bagi pertahanan, keamanan dan strategis untuk menjamin perekonomian negara dan sebagian besar hanya diizinkan untuk dimiliki oleh pihak pemerintah, contohnya minyak, uranium dan plutonium. Sementara, Bahan Golongan B dapat menjamin hayat hidup orang banyak, contohnya emas, perak, besi dan tembaga. Bahan Golongan $\mathrm{C}$ adalah bahan yang tidak dianggap langsung mempengaruhi hayat hidup orang banyak, contohnya garam, pasir, marmer, batu kapur dan asbes.

Jadi, istilah penambangan pasir dapat disimpulkan sebagai berikut kegiatan yang dilakukan untuk mengelola sumber daya alam yakni pasir yang dipergunakan untuk kepentingan hidup orang banyak.

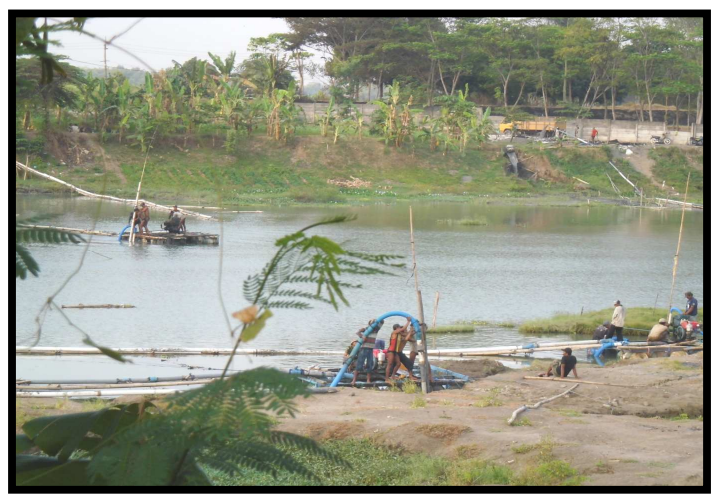

Gambar 1. Para pekerja penambang pasir liar dan mesin penghisap pasir

\section{Dampak Bencana Penambangan Pasir yang Berlebihan di Mojokerto}

\section{Banjir}

Banjir merupakan peristiwa alam yang dapat terjadi pada suatu daerah dengan menimbulkan kerugian harta benda masyarakat, merusak bangunan prasarana dan sarana serta lingkungan hidup dan bahkan merusak tata kehidupan masyarakat serta menimbulkan korban jiwa (Sangkawati dan Atmodjo, 2002).

Akibat bencana banjir, bangunanbangunan akan rusak atau hancur yang disebabkan oleh daya terjang air banjir, terseret arus, daya kikis genangan air, longsornya tanah di seputar/di bawah pondasi, tertabrak/terkikis oleh benturan dengan benda-benda berat yang terseret arus. Dalam kasus-kasus banjir selama ini, kebanyakan kerugian pangan terjadi akibat stok pangan rusak, termasuk yang masih di lahan (Sebastian, 2008).

\section{Longsor/Gerakan Tanah}

Akibat penambangan pasir yang tidak terukur penggaliannya, selain banjir 
juga dapat menyebabkan longsor. Daerah terdampak biasanya tanggul dan rumahrumah di dekat penambangan. Longsor dapat terjadi karena bagian tengah sungai menjadi dalam akibat pengerukan yang dilakukan terus menerus. Akibatnya bagian tepi sungai akan mengalami longsor, karena tanah tergerus ke tengah sungai, maka perlahan-lahan tanggul akan juga mengalami ketergerusan dan longsor. Hal ini tidak saja terjadi di tanggul-tangul sungai Berantas saja, tetapi terjadi juga di rumah-rumah dekat sungai mengalami retak-retak pada dinding. Retak-retak tersebut diakibatkan oleh longsor.

Penelitian yang intensif di lapangan merupakan bagian penting dalam mitigasi bencana gerakan tanah. Sebagai contoh, kondisi keairan dapat memberikan bahaya berupa bencana gerakan tanah. Kondisi keairan dapat diamati dan dianalisis dalam penelitian gerakan tanah antara lain sebagai berikut:

- Genangan air

- Rembesan

- Mata air

- Air tanah dangkal

- Kondisi penggunaan lahan termasuk vegetasi penutup pada wilayah lereng atau lokasi sekitarnya

- Aktivitas manusia di wilayah lereng dan sekitarnya

- Pemotongan dan atau penimbunan lereng

- Getaran peledakan, mesin, dan lalu lintas

- Penebangan hutan

- Pembuatan bangunan

- Saluran air

Dalam keputusan menteri energi dan sumber daya mineral no. $1452 \mathrm{~K} / 10 ? 2000$ tanggal 3 November 2000 batasan ukuran gerakan tanah tersebut adalah sebagai berikut:

- Gerakan tanah besar, mempunyai ukuran lebar maksimal pada sumbu tegak lurus arah gerakan tanah ( selanjutnya disebut lebar gerakan tanah) maksimal lebih besar dari 150 meter

- Gerakan tanah kecil, mempunyai lebar gerakan tanah maksimal 15 meter- 150 meter

- Gerakan tanah sangat kecil, mempunyai lebar gerakan tanah kurang dari 15 meter

Metode pemetaan zona kerentanan gerakan tanah dapat dilakukan secara langsung, tidak langsung dan gabungan. Masing-masing metode tersebut dapat dijelaskan sebagai berikut:

- Cara tidak langsung, dilakukan dengan overlayuntuk mencari pengaruh faktorfaktor yang terdapat pada peta-peta parameter terhadap sebaran (distribusi) gerakan tanah, kemudian dengan analiss menggunakan GIS (sistem informasi geografis) dapat ditentukan zonasi kerentanan gerakan tanahnya.

- Cara langsung, adalah dengan langsung memetakan di lapangan dengan memperhitungkan faktor morfologi, geologi, struktur dan lain-lain.

- Cara gabungan, adalah dengan cara overlay dua peta zona kerentanan gerakan tanah baik yang dihasilkan oleh cara langsung maupun tidak langsung, sehinga menghasilkan peta zona kerentanan gerakan tanah final/goal map.

\section{Penanggulangan Bencana di Mojokerto}

Berdasarkan Undang-Undang Nomor 24 Tahun 2007 Tentang Penanggulangan Bencana, penyelenggaraan penanggulangan bencana adalah serangkaian upaya yang meliputi penetapan kebijakan pembangunan yang berisiko timbulnya bencana, kegiatan pencegahan bencana, tanggap darurat, dan rehabilitasi. Penanggulangan bencana bertujuan untuk:

a. Memberikan perlindungan kepada masyarakat dari ancaman bencana;

b. Menyelaraskan peraturan perundangundangan yang sudah ada;

c. Menjamin terselenggaranya penanggulangan bencana secara terencana, terpadu, terkoordinasi, dan menyeluruh;

d. Menghargai budaya lokal;

e. Membangun partisipasi dan kemitraan publik serta swasta;

f. Mendorong semangat gotong royong, kesetiakawanan, dan kedermawanan;

g. Menciptakan perdamaian dalam kehidupan bermasyarakat, berbangsa, dan bernegara.

\section{Bentuk-bentuk \\ Penanggulangan Bencana}

Berdasarkan Undang-Undang Nomor 24 Tahun 2007 Tentang Penanggulangan Bencana, bentuk penanggulangan bencana meliputi:

a. Kegiatan pencegahan bencana adalah serangkaian kegiatan yang dilakukan 
sebagai upaya untuk menghilangkan dan/atau mengurangi ancaman bencana.

b. Tanggap darurat bencana adalah serangkaian kegiatan yang dilakukan dengan segera pada saat kejadian bencana untuk menangani dampak buruk yang ditimbulkan, yang meliputi kegiatan penyelamatan dan evakuasi korban, harta benda, pemenuhan kebutuhan dasar, perlindungan, pengurusan pengungsi, penyelamatan, serta pemulihan prasarana dan sarana.

c. Pasca bencana, setelah terjadi bencana, maka langkah selanjutnya adalah rehabilitasi dan rekonstruksi. Rehabilitasi adalah perbaikan dan pemulihan semua aspek pelayanan publik atau masyarakat sampai tingkat yang memadai pada wilayah pasca-bencana dengan sasaran utama untuk normalisasi atau berjalannya secara wajar semua aspek pemerintahan dan kehidupan masyarakat pada wilayah pascabencana. Sedangkan rekonstruksi adalah pembangunan kembali semua prasarana dan sarana, kelembagaan pada wilayah pascabencana, baik dari tingkat pemerintahan maupun masyarakat dengan sasaran utama tumbuh dan berkembangnya kegiatan perekonomian, sosial, dan budaya, tegaknya hukum dan ketertiban, dan bangkitnya peran serta masyarakat dalam segala aspek kehidupan bermasyarakat pada wilayah pascabencana. Proses rekonstruksi tidak mudah dan memerlukan upaya keras dan terencana serta peran semua anggota masyarakat.

Di dalam UU No 23 Tahun 1997 memuat ketentuan hak setiap orang atas lingkungan yang baik dan sehat, berarti kewajiban bagi setiap orang untuk memelihara kemampuan lingkungan hidup agar tetap dimanfaatkan untuk perlindungan dan kebutuhan manusia atau makhluk hidup lainnya, termasuk juga upaya mencegah dan menanggulangi perusakan lingkungan. Dalam undang-undang itu pula dengan adanya hak dan kewajiban tersebut melahirkan pertanggungjawaban perdata maupun sanksi pidana. Tidak hanya itu saja, tindakan yang berkaitan dengan masalah pencemaran dan perusakan lingkungan sanksinya dapat kita jumpai dalam:

1. UU No. 5 Tahun 1984 tentang
Perindustrian

\section{UU No. 9 Tahun 1985 tentang Perikanan}

Sanksi ini sudah cukup memadai untuk diterapkan pada pelaku perusakan maupun pencemaran yang disinyalir saat ini sudah banyak terjadi. Ada beberapa instansi terkait dalam menanggulangi masalah kerusakan ini, sebagaimana diatur pada pasal 34 PP No. 4 Tahun 2001, yaitu Bupati/Walikota, Gubernur dan menteri/atau kepala instansi yang bertanggung jawab.

Seiring berkembangnya teknologi yang membutuhkan sumber daya alam yang langka telah meninggalkan dampak bagi umat manusia sekarang dan generasi mendatang. Eksploitasi kekayaan alam secara tidak terbatas serta kegiatan-kegiatan lain yang menimbulkan berbagai macam pencemaran dan perusakan lingkungan.

Disamping diberlakukannya sanksisanksi tegas tentang perusakan lingkungan, juga adanya upaya partisipatif dari tokoh agama dan tokoh masyarakat untuk mengajak warganya agar segera menyadari akan bahaya yang akan muncul akibat ulah mereka (penambang pasir). Salah satu upayanya adalah memberikan lapangan pekerjaan baru bagi penambang pasir. Tidak hanya itu, pemilik penambang pasir dituntut untuk mempelajari resiko-resiko yang timbul akibat aktifitas tersebut dalam kurun waktu lama. Dengan demikian diharapkan, pemanfaatan kekayaan alam akan terukur.

\section{Mitigasi Bencana dalam Perspektif Islam}

Islam juga memberikan larangan keras untuk berbuat kerusakan di bumi. Seperti firman Allah SWT "Telah nampak kerusakan di darat dan di laut disebabkan karena perbuatan manusia tangan manusia, supaya Allah merasakan kepada mereka sebagian dari (akibat) perbuatan mereka agar mereka kembali (ke jalan yang lurus)." (QS. Ar Ruum(30);41)

Berdasarkan ayat di atas jelaslah bahwa penyebab bencana yang ada di bumi sebagian besar adalah perbuatan manusia yang mengeksploitasi sumber daya alam tidak terukur. Begitu juga pada kasus penambangan pasir ilegal di Mojokerto yang dilakukan tanpa memperhatikan rambu-rambu yang telah ditetapkan baik oleh pemerintah daerah setempat ataupun kesepakatan dengan masyarakat sekitar lokasi penambangan pasir.

Agama Islam mengajarkan kepada umatnya agar selalu menjaga dan merawat 
lingkungan. Akan tetapi banyak dari umat Islam sendiri yang melalaikan bahkan menjadi pelaku perusakan lingkungan.

Mitigasi dalam perspektif Islam maksudnya lebih bersifat 'peringatan'. Fenomena-fenomena alam yang terjadi sebenarnya sudah digambarkan jauh sebelum terjadinya bencana. Lebih jauh lagi Allah sudah memperingatkan bahwa kerusakan yang terjadi disebabkan oleh manusia. artinya jika tidak ingin terjadi sebuah kerusakan, maka kita sebagai manusia hendaknya merubah perilaku, baik vertikal maupun horizontal. Membangun kesadaran diri bahwa berbuat sesuatu yang dapat merugikan orang lain membawa dampak yang tidak kecil. Seperti adanya aktivitas penambangan pasir menyebabkan longsornya tanggu-tanggul suyngai Brantas dan rumahrumah penduduk sekitarnya banyak yang mengalami retak-retak pada dinding. Islam sebagai pedoman manusia untuk hidup di dunia, agar manusia terhindar dari berbagai macam bencana, termasuk bencana sosial, krisis moral dsb.

\section{Kesimpulan}

Berdasarkan uraian di atas, didapatkan kesimpulan bahwa Penambangan pasir liar yang terdapat disepanjang tanggul sungai Brantas Mojokerto yang membentang dari Kecamatan Gedeg sampai Kecamatan Mlirip juga disepanjang area bendungan Rolak Songo semakin lama semakin tidak terkendali. Kondisi Sungai Brantas Mojokerto yang memprihatinkan ini sudah seharusnya menjadi perhatian masyarakat dari segala lapisan. Konservasi Sungai Brantas Mojokerto tidak hanya menjadi tanggung jawab pemerintah saja. Berbagai program konservasi yang telah dilaksanakan pemerintah belum memberi hasil memuaskan karena hanya berakhir pada konsep semata.

\section{Daftar Pustaka}

Arikunto, S. 1995. Manajemen Penelitian. PT Rineka Cipta. Jakarta

Bungin, M. B. 2005. Metodologi Penelitian Kuantitatif. Edisi Pertama. Kencana Prenada Media Group. Jakarta

Erwin, M. 2008. Hukum Lingkungan. Edisi Pertama. P.T. Refika Aditama. Bandung

Kodoatie, R. J. dan R. Sjarief. 2008. Pengelolaan Sumber Daya Air
Terpadu. Edisi Revisi. Penerbit Andi. Jakarta

Koentjaraningrat. 1986. Metode-metode Penelitian Masyarakat. PT Gramedia. Jakarta

Kumar, R. 1996. Research Methodology. A Step-By-Step Guide For Beginners. Addison Wesley Longman Australia Pty Limited. Australia

Maryono, A. 2005 . Eko-Hidraulik Pembangunan Sungai. Menanggulangi Banjir dan Kerusakan Lingkungan Wilayah Sungai. Magister Sistem Teknik Program Pascasarjana. Universitas Gadjah Mada. Yogyakarta

Narbuko, C. dan A. Achmadi. 2007. Metodologi Penelitian. PT Bumi Aksara. Jakarta

Nazir, M. 2005. Metode Penelitian. Penerbit Ghalia Indonesia. Bogor Selatan

Nawawi, H. 2005. Metode Penelitian Bidang Sosial. Gadjah Mada University Press. Yogyakarta

Rosyid, D. M. 2008. Manajemen Sumber Daya Air di Jawa Timur: Beberapa Pelajaran. Bencana di Jawa Timur. Dampak dan Upaya Penanggulangannya. Editor: S. Wignjosoebroto dan B. Suyanto. Dewan Pakar Provinsi Jawa Timur. Surabaya

Rukiyati. 2002. Pengaruh Perbaikan Alur Sungai Bengawan Solo Hulu Terhadap Genangan Banjir di Daerah Surakarta. Pengelolaan Sumber Daya Air dalam Otonomi Daerah. Penerbit Andi. Yogyakarta

Sangkawati, S. dan P. S. Atmodjo. 2002. Dampak Sosial Kegiatan Pengendalian Banjir dan Konservasi Air Prioritas Utama dalam Otonomi Daerah. Pengelolaan Sumber Daya Air dalam Otonomi Daerah. Penerbit Andi. Yogyakarta

Santoso, K. 2008. Inventarisasi dan Mitigasi Wilayah Rawan Bencana di Jawa Timur. Bencana di Jawa Timur. Dampak dan Upaya Penanggulangannya. Editor: S. Wignjosoebroto dan B. Suyanto. Dewan Pakar Provinsi Jawa Timur. Surabaya 
Satori, D. dan A. Komariah. 2010. Metodologi Penelitian Kualitatif. Alfabeta. Bandung

Sebastian, L. 2008. Pendekatan Pencegahan dan Penanggulangan Banjir. Jurnal Dinamika Teknik Sipil. Volume 8. Nomor 2. Juli 2008: hal 162-169. Fakultas Teknik. Universitas Palembang

Soemanto Wasty. 2006. Psikologi Pendidikan. Edisi Keenam. P.T. Rineka Cipta. Jakarta

Sunaryo, T.M., T. Walujo S., A. Harnanto. 2005. Pengelolaan Sumber Daya Air. Konsep dan Penerapannya. Bayumedia Publishing. Malang

Suyanto, B. 2008. Dampak dan Upaya Penanganan Masyarakat Korban Bencana. Bencana di Jawa Timur. Dampak dan Upaya Penanggulangannya. Editor: S. Wignjosoebroto dan B. Suyanto. Dewan Pakar Provinsi Jawa Timur. Surabaya

Syihab, Z. H. 2009. Analisis Upaya Konservasi Mata Air "Sumber Brantas" Oleh "Stakeholder" Di Desa Sumber Brantas Kecamatan Bumiaji Kota Batu Jawa Timur. Laporan Skripsi. Manajemen Sumberdaya Perairan. Fakultas Perikanan dan Ilmu Kelautan. Universitas Brawijaya. Malang

Walgito, B. 2003. Psikologi Sosial (Suatu Pendekatan). Penerbit Andi. Yogyakarta

Wilson, E. M. 1993. Hidrologi Teknik. Penerbit ITB. Bandung 